\title{
RISK ASSESSMENTS OF WEED SEEDS ON IMPORTED FRESH PRODUCE
}

\author{
A.I. POPAY ${ }^{1}$, T.K. JAMES ${ }^{2}$, W.M.WILLIAMS ${ }^{3}$ and A. RAHMAN ${ }^{2}$ \\ ${ }^{1}$ Dept of Conservation, PO Box 112, Hamilton \\ ${ }^{2}$ AgResearch, Ruakura Research Centre, Private Bag 3123, Hamilton \\ ${ }^{3}$ AgResearch, Grasslands Research Centre, Private Bag 11008, Palmerston North
}

Corresponding author: ipopay@doc.govt.nz

\begin{abstract}
Fresh fruit, such as pineapples, imported into New Zealand, sometimes carry seeds of exotic weeds. Some of these weeds do not occur here and may, if established, threaten agriculture or the natural environment. To assist MAF in determining permissible infestation levels, the risk posed to agriculture and the environment by 12 species of weeds whose seeds occur on imported fruit was assessed. Most of these species are serious weeds in tropical and sub-tropical areas and could probably survive in New Zealand, although their distribution and adverse effects may be limited. The species that are considered most likely to be serious weeds, at least in Northland, are Chromolaena odorata, a competitive, fastgrowing shrub; the aggressive and weedy perennial grasses Brachiaria mutica, Paspalum conjugatum and Saccharum spontaneum; the annual grass Rhynchelytrum roseum; and the free seeding annual herb Ageratum conyzoides. The other species seem to pose less of a threat.
\end{abstract}

Keywords: weeds, weed risk assessment, biosecurity, fresh fruit, import contamination.

\section{INTRODUCTION}

Fresh fruit imported into New Zealand sometimes carry seeds of exotic weed species which, if established here, could become serious problems. The potential threats posed by 12 such species (Ageratum conyzoides, Borreria alata, Bothriochloa ewartiana, Brachiaria (or Urochloa) mutica, Chromolaena odorata, Cleome rutidosperma, Coccinia grandis, Dactyloctenium radulans, Digitaria brownii, Paspalum conjugatum, Rhynchelytrum roseum and Saccharum spontaneum) were evaluated using two risk assessment systems. Seed of these species had been collected as contaminants on fresh fruit and identified by the New Zealand National Seeds Laboratory in Palmerston North. The results of this study, along with germination test information and plant growth evaluations, will be used by the MAF Biosecurity Authority to help set maximum pest levels (MPLs) - the number of seeds per fruit that are acceptable for imports.

\section{METHODS}

For each of the 12 species, information on form, ecology, distribution and weed status was collected. This information was used in two weed risk assessment (WRA) systems. It was assumed that all species could establish in New Zealand, at least in northern areas.

The first WRA, devised by Pheloung (1996) and revised for New Zealand by Pheloung et al. (1999), is based on 49 questions about the main attributes and impact of a weed. Final scores range from minus 14 , for a benign species, to plus 29 , the maximum weediness score. A score of less than 0 means the species can be accepted into the country, 1 to 6 that further evaluation is necessary, while 7 or more indicates the species should not be allowed entry. 
The second WRA, devised by Williams et al. (2002), assesses possible conservation threats posed by weeds and is made up of two scores. The first, of up to 20, is for the naturalisation and weedy behaviour of the species' family and genus. Plants with a score of 6 or less would be unlikely to become conservation weeds. The second, of up to 5 , relates to the species' reproductive capacity, dispersal by humans, visibility and resistance to management. Species with scores of more than 3 are considered likely to spread or be difficult to control or both.

\section{Brief profiles of each species}

\section{RESULTS}

Ageratum conyzoides, a free-seeding annual weed of crops and waste areas, widespread in the tropics and sub-tropics, is an erect, branching herb up to $1 \mathrm{~m}$ tall. Ageratum conyzoides and A. houstonianum occur on the north coast of New South Wales and in eastern Queensland. Ageratum houstonianum is also found in central coastal New South Wales, and A. conyzoides in Northern Territory. Ageratum houstonianum is common in waste places and disturbed areas on Raoul Island (Webb et al. 1988). Cultivars of $A$. houstonianum are grown as summer annuals in British gardens. Distribution of the two species suggests that $A$. houstianum is tolerant of slightly cooler conditions that $A$. conyzoides.

Borreria alata (also known as Speramacoce alata) and $B$. (=S.) latifolia are lowgrowing annual (B. alata) or perennial (B. latifolia) broadleaf weeds that have spread noticeably over the last 20 years to become serious crop weeds in the Caribbean, West Africa and South Pacific Islands. Borreria latifolia occurs as a weed of sugar cane in Queensland and the Northern Territory of Australia. Two related species (S. assurgens and $S$. hispida) occur in Northern Territory and Queensland.

Bothriochloa ewartiana, a 60-90 cm high perennial grass, occurs in central Australia on river banks, drainage floors, valley slopes or stony hills. The species is not reported as a serious weed, although $B$. pertusa and $B$. macra have weedy characteristics. Bothriochloa pertusa, naturalised in Queensland and Northern Territory, is grown as fodder and occurs as a weed. Bothriochloa macra is a perennial coloniser of disturbed and degenerated areas and roadsides throughout Australia, introduced in Tasmania. It occurs in New Zealand 'North Auckland to Auckland City, Cuvier Island, Gisborne, Nelson, Marlborough' (Edgar \& Connor 2000). Another species, B. bladhii, is found on Raoul Island.

Brachiaria (or Urochloa) mutica, found on Raoul Island in a long-abandoned orchard, is a coarse, trailing perennial grass, widely introduced into tropical areas as a pasture grass, and mainly a weed of wet areas. It is somewhat shade-tolerant and very susceptible to frost. It is used in Queensland in 'ponded systems', grassy dams used to provide dryseason feed for stock, but is seen as an environmental threat to waterways. It does not apparently occur in New South Wales, which makes it unlikely that New Zealand would provide warm enough conditions for it to thrive and become widespread.

Chromolaena odorata, common in the tropics, is an erect or sprawling, fast-growing shrub that forms dense tangled thickets 1.5 to $5 \mathrm{~m}$ high or higher. It is very competitive with pastures and plantation crops, and is a fire hazard and threat to natural areas. The species, discovered in Queensland in 1993, is being eradicated. It is widely recognised as a dangerous weed. McFadyen \& Skarratt (1996) demonstrated its potential to establish in New Zealand.

Cleome rutidosperma/viscosa is a white-flowered annual herb usually growing up to $0.5 \mathrm{~m}$ high. It is invasive on Nuie, and its presence in central Australia is causing some concern there. A related species, $C$. hassleriana, occurs as a rare garden escape in Auckland, Nelson, Christchurch and Otago. These are not usually considered seriously competitive weeds. These species could survive here as summer annuals, but are unlikely to pose a major threat to New Zealand.

Coccinia grandis is a vine proving very invasive on Hawaii and found in other Pacific islands, including Fiji, Tonga and Vanuatu. It can be a very aggressive weed of natural areas and sometimes smothers forest. 
Dactyloctenium radulans (= Eleusine radulans), a soft, sprawling, tufted annual grass up to $30 \mathrm{~cm}$ in height, is found in all states of Australia except Tasmania. In northern Queensland pastures it can become dominant under heavy grazing, and occurs as a weed of gardens, cultivation and roadsides. It also occurs in three southern States of the USA. It is not reported as a serious weed anywhere, although D. aegyptium is a serious weed in tropical countries.

Digitaria brownii is a tussock-forming perennial grass found in central Australia. There it is considered a valuable pasture perennial, with relatively soft foliage that is highly palatable to stock. It is not, apparently, regarded as a weed.

Paspalum conjugatum occurs on Raoul Island on old grassy tracks in semi-shade. The single record from the North Island was in a thermal area at Ohinemutu, Rotorua, where it has not been seen recently (E. Cameron, pers. comm.). The species is widespread in the tropics and subtropics, where it is an aggressive and persistent perennial stoloniferous grass that rapidly invades wet habitats, often forming a dense ground cover. It has led to the extinction of some native forests. In Australia it is a serious weed of orchards, vineyards, sugar cane, lawns, golf course and waterways in northern Queensland and the north coast of NSW

Rhynchelytrum roseum ( $=R$. repens) was collected in North Auckland in 1909 and again from Takapau in Hawke's Bay about 30 years later (Edgar \& Connor 2000). This annual grass weed commonly colonises bare ground in tropical and some temperate areas, but is not considered particularly competitive. In Australia it is a widespread roadside and railway embankment weed, particularly in coastal NSW and Queensland, but also on NSW slopes and plains and in Victoria, Northern Territory and Queensland.

Saccharum spontaneum is a perennial, rhizomatous grass sometimes used in sugar cane breeding programmes. It is widely distributed in Asia and parts of the Pacific, has wind-borne seed, and is regarded as a serious weed in some places. It tends to be restricted to tropical areas, although it does grow in northern India.

\section{Weed risk assessments}

Results of the weed risk assessments are shown in Table 1. According to these assessments, the worst potential weed is Chromolaena odorata, with high scores for many features that could make it a fearsome weed. Paspalum conjugatum is not far behind it on weed scores. The other two perennial grasses, Brachiaria mutica and Saccharum spontaneum, come next and again are found mainly in tropical areas. Ageratum conyzoides, sometimes a serious annual weed of crops, has a moderate score for weediness. The two annuals, Cleome rutidosperma and Rhynchelytrum repens, have low weediness scores, mostly ranking as weeds of open ground rather than as serious weeds of crops. Digitaria brownii seems to have few weedy characters.

\section{DISCUSSION}

All the weeds evaluated in this study could probably find a niche somewhere in New Zealand. In many cases that niche would be small, as many of the weeds are widespread in the tropics, but do not stray far into temperate areas. Some of them-notably $B$. mutica, C. odorata, $P$. conjugatum and $S$. spontaneum - have the potential to be very serious weeds of both agriculture and the environment as they are in other countries. However, this would be only in northern areas and, for some of them, only in sheltered areas of Northland. Brachiaria mutica, for example, is very susceptible to frost. Coccinia grandis is proving a serious weed of native environments in Pacific islands and could, with its relatively high conservation WRA score, become a problem in such areas here.

The other species, too, could probably establish here but are unlikely to be competitive with other species, and would probably only survive in open, disturbed habitats in warm northern areas. Ageratum conyzoides and D. brownii scored very highly on the conservation WRA (which is heavily reliant on the weedy behaviour of related species): the former has demonstrated its weediness potential overseas (Holm et al. 1977), whereas the latter has not. 
TABLE 1: Weed risk and conservation weed risk assessment scores using two systems. Weeds already established here are shown in bold.

\begin{tabular}{|c|c|c|c|c|}
\hline & \multicolumn{2}{|c|}{ Pheloung et al. (1999) } & \multicolumn{2}{|c|}{ Williams et al. (2002) } \\
\hline & $\begin{array}{l}\text { New Zealand } \\
\text { weed score }\end{array}$ & $\begin{array}{l}\text { Accept/ } \\
\text { Evaluate/ } \\
\text { Reject1 }\end{array}$ & $\begin{array}{l}\text { Chance of } \\
\text { becoming a } \\
\text { conservation } \\
\text { weed }\end{array}$ & $\begin{array}{l}\text { Potential for } \\
\text { spread and } \\
\text { control } \\
\text { difficulty }\end{array}$ \\
\hline Rubus fruticosus & 29 & $\mathbf{R}$ & 16 & 4 \\
\hline Sorghum halepense & 25 & $\mathbf{R}$ & 16 & 3 \\
\hline Chromolaena odorata & 23 & $\mathrm{R}$ & 12 & 2 \\
\hline Senecio jacobaea & 22 & $\mathbf{R}$ & 14 & 3 \\
\hline Paspalum conjugatum & 22 & $\mathrm{R}$ & 16 & 3 \\
\hline Brachiaria mutica & 21 & $\mathrm{R}$ & 12 & 3 \\
\hline Saccharum spontaneum & 17 & $\mathrm{R}$ & 12 & 3 \\
\hline Rhynchelytrum roseum & 14 & $\mathrm{R}$ & 12 & 2 \\
\hline Ulex europaeus & 13 & $\mathbf{R}$ & 16 & 3 \\
\hline Ageratum conyzoides & 12 & $\mathrm{R}$ & 15 & 3 \\
\hline Borreria alata & 12 & $\mathrm{R}$ & 7 & 2 \\
\hline Cleome rutidosperma & 12 & $\mathrm{R}$ & 9 & 3 \\
\hline Dactyloctenium radulans & 12 & $\mathrm{R}$ & 11 & 2 \\
\hline Coccinia grandis & 8 & $\mathrm{R}$ & 13 & 4 \\
\hline Bothriochloa ewartiana & 6 & $\mathrm{E}$ & 11 & 2 \\
\hline Digitaria brownii & 4 & $\mathrm{E}$ & 16 & 2 \\
\hline
\end{tabular}

${ }^{1}$ Reject means reject for importation, accept means allow importation and evaluate means more information is needed.

\section{ACKNOWLEDGEMENTS}

The authors are grateful to Peter Williams for checking and commenting on the weed risk assessments.

\section{REFERENCES}

Edgar, E.; Connor, H.E. 2000: Flora of New Zealand. Vol V. Grasses. Manaaki Whenua Press, Christchurch.

Holm, L.G; Plucknett, D.L.; Pancho, J.V.; Herberger, J.P. 1977: The World's Worst Weeds. University Press of Hawaii, USA.

McFadyen, R.E.C.; Skarratt, B. 1966: Potential distribution of C. odorata (Siam weed) Australia, Africa and Oceania. Agric. Ecosyst. Environ. 56: 89-96.

Pheloung, P. C. 1996: Predicting the weed potential of plant introductions. Proc. Aust. Weed Conf. 11: 462-463.

Pheloung, P.C.; Williams, P.A.; Halloy, S.R. 1999: A weed risk assessment model for use as a biosecurity tool evaluating plant introductions. J. Environ. Mgt 57: 239251.

Webb, C.J.; Sykes, W.R.; Garnock-Jones, P.J. 1988: Flora of New Zealand. Vol IV. Naturalised pteridophytes, gymnosperms, dicotyledons. Botany Division, DSIR, Christchurch.

Williams, P.A.; Wilton, A.; Spencer, N. 2002: A proposed conservation weed risk assessment system for the New Zealand border. Science for Conservation 208. NZ Dept of Conservation, Wellington. $47 \mathrm{p}$. 